\title{
Effect of Some Preservative Solutions on Vase Life of Gladiolus Cut Flowers
}

\author{
Thanaa M. Ezz ${ }^{1}$, M. A. Aly ${ }^{1}$, Bothaina M. Weheda ${ }^{2}$, M. K. Gaber ${ }^{1}$ \\ and Azza M. Abd El-Rahman ${ }^{2}$ \\ 1. Department of Plant Production - Faculty of Agriculture (Saba-Basha) - Alexandria \\ University. \\ 2. Horticulture Research Institute.
}

\begin{abstract}
Keeping quality and length of vase life are important factors for evaluation of cut flowers quality, for both domestic and export markets. These investigations proposed to determine the effectiveness of some preservative solutions as glutamic acid (100, 200 and 300 $\mathrm{mg} / \mathrm{l})$, salicylic acid $(200,400$ and $600 \mathrm{mg} / \mathrm{l})$, calcium chloride $(1000,2000$ and $3000 \mathrm{mg} / \mathrm{l})$ and aluminum sulphate $(100,200$ and $300 \mathrm{mg} / \mathrm{l})$ on quality parameters of (Gladiolus grandiflorus L. cv. 'Rose Supreme') flowers. Results showed that all treatments significantly increased the vase life, fresh weight, water uptake and chlorophyll content with decreasing number of bacteria and proline accumulation compared to control. The highest increase in fresh weight, water uptake and chlorophyll index was obtained by glutamic acid $(300 \mathrm{mg} / \mathrm{l})$, salicylic acid $(400 \mathrm{mg} / \mathrm{l})$, calcium chloride $(3000 \mathrm{mg} / \mathrm{l})$ and aluminum sulphate $(300 \mathrm{mg} / \mathrm{l})$. Whilst, glutamic acid $(300 \mathrm{mg} / \mathrm{l})$ and salicylic acid (400) resulted in the maximum vase life in both experiments, in addition, glutamic acid $(200 \mathrm{mg} / \mathrm{l})$ and aluminum sulphate $(200$ and $300 \mathrm{mg} / \mathrm{l})$ in second experiment. Moreover, glutamic acid (300 mg/l) recorded the most effect on decreasing number of bacteria and proline accumulation in both experiments, furthermore salicylic (400 and $600 \mathrm{mg} / \mathrm{l})$, calcium chloride $(3000 \mathrm{mg} / \mathrm{l})$ and aluminum sulphate $(100,200$ and $300 \mathrm{mg} / \mathrm{l})$ on number of bacteria and salicylic acid (200 and $400 \mathrm{mg} / \mathrm{l})$, calcium chloride (3000 mg/l) and aluminum sulphate $(100,200$ and $300 \mathrm{mg} / \mathrm{l}$ ) on proline accumulation in first experiment compared to control.
\end{abstract}

Key words: Gladiolus, vase life, preservative solutions, cut flowers

\section{INTRODUCTION}

Gladiolus (Gladiolus grandiflorus L.) is an ornamental plant native to South Africa. It belongs to family Iridaceae, having approximately one hundred and fifty known species. This plant is commercially used for cut flowers and occasionally used for landscape purpose. Gladiolus is one of the few plants which produce pleasant cut flowers with long spikes. It is cultivated in most of the tropical and subtropical countries of the world (Adil et al., 2013). Gladiolus flowers are considered main exportable ornamental plants in Egypt, and the flower can be available year-around, the foreign markets demand Egyptian Gladiolus with higher quality (Abo-Leila and Eid, 2011). In addition, there is high demand of Gladiolus in the world as cut flower. In USA, 60 million Gladiolus spikes were sold in the market having worth of 16 million dollars which is $4.5 \%$ of total produced cut flowers in 2011 (USDA, 2012). Gladiolus is a popular cut flower in the world, but its longevity is very short. The vase life of individual florets is 4 to 6 days. Life of cut flowers is mainly affected by two main factors, namely ethylene which accelerates the senescence of many flowers and by microorganisms which cause vascular blockage and thus reduces the vase life of cut flowers (Mohammadi et al., 2014). Several chemicals solutions were used as pulsing or preservative solutions for increasing the longevity of cut flowers. Those chemicals are very expensive and most harmful preservative for human causing irritating to skin, eyes and respiratory tract as well as using natural products did not have large attentions as safe materials in vase 
solutions (Mohamed, 2015). The maintenance of vase life is an important quality attribute in these economically significant cut flowers. A suitable method for vase life extension, which easy to use, natural, safe and inexpensive compounds is always crucial in this respect for large-scale applications (Soleimany-Fard et al., 2013). Glutamine, a multifaceted amino acid used as an energy substrate for most cells. Glutamine plays an important role in the nitrogen and carbon skeleton exchange among different tissues, where this amino acid fulfils many different physiological functions (Zamani et al., 2011). Salicylic acid (SA) is considered to be a potent plant hormone because of its diverse regulatory roles in plant metabolism. SA has been found to play a key role in the regulation of plant growth, development and in responses to environmental stresses. Further, its role is evident in ion uptake and transport, photosynthetic rate, stomatal conductance and transpiration (Tehranifar et al., 2013). Calcium chloride is widely used as preservative and firming agent in the fruits and vegetables industry for whole and fresh-cut commodities (MartinDiana et al., 2007). Aluminum sulphate is used as an antimicrobial compound in commercial preservative solutions (Zadeh and Mirzakhani, 2012). Aluminum sulphate acidifies vase solution, diminishes bacterial proliferation and enhances water uptake (Liao et al., 2001). The aims of this study were to determine the effectiveness of some materials (glutamic acid, salicylic acid, calcium chloride and aluminum sulphate) as preservation treatments to reduce Gladiolus cut flowers senescence and increase vase life. Moreover, to find out the most effective concentration among materials used to produce the best quality cut flower with longer vase life.

\section{MATERIALS AND METHODS}

Two separated experiments were conducted in the Plant Production Department, Faculty of Agriculture, Saba Basha, Alexandria University in (April and November, 2015) on Gladiolus cut flowers. This study was carried out to study the effect of glutamic acid, salicylic acid, calcium chloride and aluminum sulphate treatments on vase life of Gladiolus cut flowers (Rose Supreme variety). Cut flowers were obtained from a well-known commercial nursery in Cairo. Cut spikes were cut from the field in early morning, wrapped with polyethylene sheet, and then quickly moved to the laboratory, of an average temperature of $\left(18^{\circ} \mathrm{C} \pm 1\right)$ and $(50-60 \%)$ relative humidity and light from a white fluorescent lamp. Each stem was recut to a length of $60 \mathrm{~cm}$ before postharvest treatments. Leaves of the lower third part of the stem were removed to avoid contamination in the vase solution as recommended by Khimani et al. (2005). After that, flower stems were pulsed in freshly solutions which prepared at the start of experiments from (concentrations of glutamic acid, salicylic acid, calcium chloride, aluminum sulphate) in plastic container for 24 hours. Then the flowers were moved to glass containers (vases) which contained $300 \mathrm{ml}$ of tap water to calculate the vase life and the tested parameters. 


\section{Treatments and design}

The treatments were arranged in a factorial experiment with Randomized Complete Block Design (RCBD) in two factors (Materials and Concentrations) with 3 replications. All data obtained throughout the course of this study were statistically analyzed by the analysis of variance as described by Steel and Torrie (1980), all analysis were done by Average of SAS (2002) statistical software. Cut flowers were pulsed in concentrations of glutamic acid $(100,200$ and $300 \mathrm{mg} / \mathrm{l})$, salicylic acid (200, 400 and $600 \mathrm{mg} / \mathrm{l})$, calcium chloride (1000, 2000 and $3000 \mathrm{mg} / \mathrm{l})$ and aluminum sulphate (100, 200 and $300 \mathrm{mg} / \mathrm{l})$ with Litter tap water and $1 \%$ sucrose in the same time, control cut flowers pulsed in 2liter tap water and $1 \%$ sucrose for 24 hours.

\section{Vase Life (days):}

Was determined when the seventh floret in the spike wilted as recommended by Badr et al. (2008).

\section{Total Fresh Weight (g):}

The average fresh weight of fresh stems carrying leaves and the flowers were calculated at the full opening stage (Barakat, 2013).

\section{Water Uptake (g):}

The volume of water uptake was calculated by subtracting the volume of water evaporated from a control vase without cut flowers and the amount of water decreased in vases containing flowers (Zamani et al., 2011).

\section{Chlorophyll Index (SPAD):}

Chlorophyll index was measured by chlorophyll meter (SPAD- 502, Minolta Co. Japan). Average of 3 measurements from different spots of a single leaves was considered (Yadava, 1986).

\section{Number of Bacteria (CFU/ml):}

Bacterial contamination was determined in the keeping solution at the end of experiment. The samples of the preservative solutions were taken $(1 \mathrm{ml}$ of each) and diluted using sterilized distilled water. One $\mathrm{ml}$ of each diluted solution was streaked on nutrient agar into Petri dishes. Cultures were incubated 2 days at $28^{\circ} \mathrm{C}$ and the colonies appearing on the plates were counted. This experiment was repeated two times with 3 replicates in each treatment at the laboratory of Microbiology Department, Faculty of Agriculture, Saba Basha, Alexandria University (Gendy and Mahmoud, 2012).

\section{Determination of Proline Content in Leaves ( $\mu \mathrm{g}$ proline $/ \mathrm{g}$ ):}

Proline colorimetric determination proceeded according to Bates et al. (1973), Marin et al. (2009) based on proline's reaction with ninhydrin. For proline colorimetric determinations, a 1:1:1 solution of proline, ninhydrin acid and glacial acetic acid was incubated at $100^{\circ} \mathrm{C}$ for 1 hour. The reaction was arrested in an iced bath and the cromophore was extracted with $4 \mathrm{ml}$ toluene and its absorbance at $520 \mathrm{~nm}$ was determined in a Bio Mate spectrophotometer (Thermo Spectronic). 


\section{RESULTS AND DISSCUSSION}

\section{Total Fresh Weight (g)}

Data in Tables 1 and 2 generally, revealed that, all treatments significantly increased fresh weight compared with the control in first and second experiment (April and November, 2015). In addition, the statistically analyzed data indicated that glutamic acid $(300 \mathrm{mg} / \mathrm{l})$, salicylic acid $(400 \mathrm{mg} / \mathrm{l})$, calcium chloride $(3000 \mathrm{mg} / \mathrm{l})$ and aluminum sulphate $(300 \mathrm{mg} / \mathrm{l})$ were more effective on increasing fresh weight than other treatments. The change in fresh weight of Gladiolus cut flowers was increased with increasing vase life periods.

Results are similar to those of Zamani et al. (2011) on Rose cut flower and Mazher et al. (2011) on Codiaeum variegatum L. plants, they observed that treatments with glutamic acids had a significant effect on fresh weight. These results seemed to be due to the reduction of MDA (malonyldialdehyde) accumulation, the microbial populations on vase solution of cut flower and ACC oxidase activity (Aminocyclo propane carboxylate oxidase) and improved membrane stability confirmed by Aran et al. (2011) similarly Kazemi et al. (2012c).

With regard to salicylic acid treatments, the findings proved to be in accordance to results of Mashhadian et al. (2012) on Chrysanthemum and Marandi et al. (2011) on Gladiolus, they reported that salicylic acid enhanced the fresh weight also, Sabzi et al. (2012) and Ashtari et al. (2013) on Rose cut flowers. We could return this increase of fresh weight by treatments of salicylic acid to its antimicrobial activity (inhibiting vascular blockage), it increases water uptake and decrease transpiration rate, thereby enhancing water balance of cut flowers which might be because of the possibility of salicylic acid to decrease $\mathrm{pH}$ of vase solution and consequently, the growth and proliferation of bacteria is reduce, which increase water uptake as proved by Soleimany-Fard et al. (2013).

Similarly, Sardoei (2014) and Ibrahim et al. (2011) on Narcissus tazetta and Gerbera jamesonii; respectively indicated that the effect of calcium chloride on fresh weight of cut flowers was significant. These results may be referred to the role of calcium in maintenance and modulation of various cell functions as the main role of integrated biocide in floral preservatives is to sustain clarity in vase solution and to avoid blockage of xylem elements by microorganisms as confirmed by Sardoei (2014). Moreover, Cortes et al. (2011) indicated that calcium increases tissue resistance by slowing senescence because it inhibits the synthesis or action of ethylene.

On other hand, Viradia et al. (2015) and Seyf et al. (2012) observed that aluminum sulphate significantly enhanced the fresh weight for longer period in Tuberose and Rose cut flowers compared to control treatments. In general, aluminum sulfate had significant effect on fresh weight loss, this might be related to solution uptake enhancement, improved water relations and prevent vascular blockage by microorganisms which finally resulted extension in vase life as indicated by Mohammadi et al. (2012) and Hussen and Yassin (2013). 
Regarding the effect of vase life periods on the change in fresh weight of Gladiolus cut flowers it was found that fresh weight increased with increasing vase life periods and the differences among all tested vase life periods were statistically significant, except for the last sampling date (20 days) where the difference was significantly decreased in two separated experiment compared with initial time. The increase in fresh weight might be due to the improvements in water balance which is a major factor determines quality and longevity of cut flowers. It is influenced by water uptake and transpiration, being balance between these two processes. Low water uptake is often due to occlusions located mainly in the basal stem end and microbes are common cans of stem end blockage as described by Hajizadeh et al. (2012) and Sardoei (2014) who observed that obstruction of the xylem by bacteria, therefore, inability of water absorption by flower steams is one of the current problems that lead to decrease in flowers postharvest longevity and also early welter of them.

Table (1). Effect of some preservative solutions on fresh weight (g) of Gladiolus cut flowers "Rose Supreme" in the first experiment (April, 2015).

\begin{tabular}{|c|c|c|c|c|c|c|}
\hline \multicolumn{7}{|c|}{ Total Fresh Weight (g) (April, 2015) } \\
\hline \multirow[b]{2}{*}{ Treatments } & \multicolumn{6}{|c|}{ Vase Life (Days) } \\
\hline & $\begin{array}{c}\text { Initial } \\
\text { Time }\end{array}$ & 5 & 10 & 15 & 20 & Average \\
\hline Control & $31.87 e$ & $53.04 \mathrm{~g}$ & $51.81 \mathrm{e}$ & $37.13 \mathrm{~d}$ & $14.07 f$ & $37.58 f$ \\
\hline Glutamic acid 100 mg/l & $33.15 d$ & 55.49 cde & $53.55 \mathrm{bcd}$ & $39.33 b c$ & $16.36 \mathrm{cde}$ & 39.58de \\
\hline Glutamic acid 200 mg/l & $33.43 \mathrm{c}$ & $55.72 \mathrm{~cd}$ & $54.25 b$ & $39.59 \mathrm{bc}$ & $16.31 \mathrm{cde}$ & $39.86 \mathrm{~cd}$ \\
\hline Glutamic acid 300 mg/l & $33.81 a$ & $56.52 a$ & $56.41 \mathrm{a}$ & $41.58 \mathrm{a}$ & $18.25 a$ & $41.31 \mathrm{a}$ \\
\hline Salicylic acid 200 mg/l & $33.62 b$ & 55.34def & $52.97 \mathrm{cde}$ & $39.42 b c$ & $16.24 \mathrm{cde}$ & 39.52de \\
\hline Salicylic acid 400 mg/l & $33.9 a$ & $56.25 a b$ & $55.77 a$ & $41.43 a$ & $18.03 a$ & $41.08 \mathrm{a}$ \\
\hline Salicylic acid $600 \mathrm{mg} / \mathrm{l}$ & $33.36 \mathrm{c}$ & $55.67 \mathrm{~cd}$ & $52.50 \mathrm{de}$ & $39.21 b c$ & $15.37 e$ & $39.22 \mathrm{e}$ \\
\hline Calcium chloride $1000 \mathrm{mg} / \mathrm{l}$ & $33.12 d$ & 55.14 ef & $53.33 \mathrm{bcd}$ & $39.26 \mathrm{bc}$ & 15.71de & $39.31 e$ \\
\hline Calcium chloride $2000 \mathrm{mg} / \mathrm{l}$ & $33.39 c$ & $55.73 \mathrm{~cd}$ & $53.69 \mathrm{bcd}$ & $39.38 \mathrm{bc}$ & $16.76 \mathrm{bcd}$ & $39.79 \mathrm{~cd}$ \\
\hline Calcium chloride $3000 \mathrm{mg} / \mathrm{l}$ & $33.64 b$ & $56.21 \mathrm{ab}$ & $55.64 a$ & $39.85 b$ & $17.65 a b$ & $40.60 \mathrm{~b}$ \\
\hline Aluminum sulphate $100 \mathrm{mg} / \mathrm{l}$ & $33.05 d$ & $55.00 f$ & $52.99 \mathrm{cde}$ & $38.57 \mathrm{c}$ & $16.20 \mathrm{de}$ & $39.16 e$ \\
\hline Aluminum sulphate $200 \mathrm{mg} / \mathrm{l}$ & $33.34 \mathrm{c}$ & $55.36 \mathrm{def}$ & $53.37 \mathrm{bcd}$ & $39.58 \mathrm{bc}$ & $16.50 \mathrm{~cd}$ & 39.63de \\
\hline Aluminum sulphate $300 \mathrm{mg} / \mathrm{l}$ & $33.58 \mathrm{~b}$ & $55.85 \mathrm{bc}$ & $54.11 \mathrm{bc}$ & $40.16 b$ & $17.34 \mathrm{abc}$ & $40.21 b c$ \\
\hline Average & 33.33d & 55.49 a & $53.88 \mathrm{~b}$ & $39.58 \mathrm{c}$ & $16.52 \mathrm{e}$ & 39.76 \\
\hline LSD at 0.05 & \multicolumn{2}{|r|}{ T: 0.47} & \multicolumn{2}{|c|}{ D: 0.29} & \multicolumn{2}{|c|}{ T×D: 1.07} \\
\hline T: Treatmer & & D: Vase Life & & 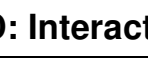 & & \\
\hline
\end{tabular}


Table (2). Effect of some preservative solutions on fresh weight (g) of Gladiolus cut flowers "Rose Supreme" the in second experiment (November, 2015).

\begin{tabular}{|c|c|c|c|c|c|c|}
\hline \multicolumn{7}{|c|}{ Total Fresh Weight (g) (November, 2015) } \\
\hline \multirow[b]{2}{*}{ Treatments } & \multicolumn{6}{|c|}{ Vase Life (Days) } \\
\hline & $\begin{array}{c}\text { Initial } \\
\text { Time }\end{array}$ & 5 & 10 & 15 & 20 & Average \\
\hline Control & $31.19 \mathrm{c}$ & $55.77 \mathrm{~g}$ & $51.05 \mathrm{e}$ & $31.98 \mathrm{c}$ & $22.42 \mathrm{~g}$ & 38.48d \\
\hline Glutamic acid $100 \mathrm{mg} / \mathrm{l}$ & $31.24 \mathrm{c}$ & $58.31 \mathrm{edf}$ & $52.72 \mathrm{cde}$ & $36.06 \mathrm{ab}$ & $25.18 \mathrm{~cd}$ & $40.70 \mathrm{bc}$ \\
\hline Glutamic acid $200 \mathrm{mg} / \mathrm{l}$ & $31.54 b$ & 59.40 cde & $53.25 \mathrm{~cd}$ & $36.09 a b$ & $25.04 \mathrm{cde}$ & $41.06 \mathrm{bc}$ \\
\hline Glutamic acid $300 \mathrm{mg} / \mathrm{l}$ & $31.89 a$ & $63.00 \mathrm{a}$ & $57.67 a$ & $37.34 a$ & $28.83 a$ & $43.74 a$ \\
\hline Salicylic acid 200 mg/l & $31.35 \mathrm{bc}$ & $58.51 \mathrm{def}$ & $53.18 \mathrm{~cd}$ & $36.18 \mathrm{ab}$ & 23.84ef & $40.61 \mathrm{bc}$ \\
\hline Salicylic acid 400 mg/l & $31.84 a$ & $61.28 a b$ & $56.93 a$ & $37.26 a$ & $27.52 b$ & $42.97 a$ \\
\hline Salicylic acid 600 mg/l & $31.55 b$ & 58.57def & $52.28 \mathrm{de}$ & $33.95 b c$ & $23.25 f g$ & $39.92 \mathrm{c}$ \\
\hline Calcium chloride $1000 \mathrm{mg} / \mathrm{l}$ & $31.21 \mathrm{c}$ & $57.01 \mathrm{fg}$ & $54.48 b c$ & $36.15 a b$ & 23.95ef & $40.56 \mathrm{bc}$ \\
\hline Calcium chloride 2000 mg/l & $31.39 b c$ & 58.02ef & $54.48 c d$ & $34.84 a b$ & $25.28 c d$ & $40.66 \mathrm{bc}$ \\
\hline Calcium chloride $3000 \mathrm{mg} / \mathrm{l}$ & $31.57 b$ & $59.92 \mathrm{bcd}$ & $56.18 a b$ & $34.11 b c$ & $25.96 \mathrm{c}$ & $41.55 b$ \\
\hline $\begin{array}{l}\text { Aluminum sulphate } 100 \\
\mathrm{mg} / \mathrm{l}\end{array}$ & $31.35 \mathrm{bc}$ & $57.01 \mathrm{fg}$ & $53.40 \mathrm{~cd}$ & $35.73 a b$ & $24.56 \mathrm{de}$ & $40.41 b c$ \\
\hline $\begin{array}{l}\text { Aluminum sulphate } 200 \\
\mathrm{mg} / \mathrm{l}\end{array}$ & $31.51 b$ & 58.47def & $53.49 \mathrm{~cd}$ & $33.93 b c$ & 24.17def & $40.31 b c$ \\
\hline $\begin{array}{l}\text { Aluminum sulphate } 300 \\
\mathrm{mg} / \mathrm{l}\end{array}$ & $31.39 b c$ & $60.61 \mathrm{bc}$ & $53.8 \mathrm{~cd}$ & $34.80 a b$ & 24.1 def & $40.94 b c$ \\
\hline Average & $31.46 \mathrm{~d}$ & $58.91 a$ & $54.02 b$ & $35.26 \mathrm{c}$ & $24.93 e$ & 40.92 \\
\hline LSD at 0.05 & \multicolumn{2}{|c|}{$\mathrm{T}: 1.34$} & \multicolumn{2}{|c|}{ D: 0.83} & \multicolumn{2}{|c|}{ T×D: 3.05} \\
\hline T: Treatme & & D: Vase Lif & $T \times I$ & : Interact & & \\
\hline
\end{tabular}

Water Uptake (g)

Data in Tables 3 and 4 revealed that all used materials significantly enhanced water uptake compared with the control in first and second experiment (April and November, 2015).Data also showed that glutamic acid (300 mg/l), salicylic acid (400 mg/l), calcium chloride (3000 mg/l) and aluminum sulphate $(300 \mathrm{mg} / \mathrm{l})$ caused the greatest water uptake. The increase of water uptake in glutamic acid pulsed stems might be due to decreasing accumulation of bacteria in vase solution which increased water absorption and ACC- oxidase activity (Aminocyclo propane carboxylate oxidase) which relatively has affected on the senescence process as proved by Aran et al. (2011). These results are compatible with the findings of Kazemi et al. (2012a) on Gerbera, who indicated that glutamine treatments increased cut flowers water absorption.

The enhancing effect of salicylic acid on water uptake may be related to the role of salicylic acid in reducing the microbial population in vase solution of cut flowers and/or positive regulatory role of SA on stomatal closure which regulates the rates of transpiration and increases the water-retaining capacity of leaves and petals as demonstrated by Kazemi et al. (2011a, b, and c) and 
Khenizy et al. (2013). In addition, the role of salicylic acid is evident in ion uptake and transport and also photosynthetic rate, stomatal conductance and transpiration Khan et al. (2003). Similar results were obtained by Kazemi et al. (2011c) on Gerbera, Zadeh and Mirzakhani (2012) on Carnation and Soleimany-Fard et al. (2013) on Alstroemeria cut flower, they revealed that salicylic acid increased water absorption compared to control.

Concerning calcium chloride, results are similar with Sardoei (2014) findings on Narcissus (Narcissus tazetta), Ibrahim et al. (2011) on Gerbera, Farahat and Gaber (2009) on Monestera deliciosa and Cortes et al. (2011) on Rosa hybrid, they revealed that calcium chloride treatments increased water uptake compared to control. Thus seemed to be referred to the important role of calcium in increasing tissue resistance and delaying senility through preventing ethylene synthesis and it's processing. It was shown that the use of calcium in vase solutions increases water flow through the stem by association with pectin in the xylem cell walls (Zadeh and Mirzakhani 2012).

Regarding aluminum sulphate, results are consistent with Nader et al. (2015), Seyf et al. (2012) on Rose cut flowers. These significant effect of aluminum sulphate on water uptake which observed in Tables 3 and 4 might be attributed to the action of aluminum sulphate which inhibited vascular blockage and increased absorption of water, ultimately increased the uptake of water in the spike Viradia et al. (2015) and Tsegaw et al. (2011).

Results also indicated that water uptake of Gladiolus cut flowers was increased with increasing vase life periods and the differences among all tested vase life periods were statistically significant, except for the last sampling date (20 days) where the difference was significantly decreased in both experiments compared with initial time. The decrease in water uptake of cut flowers during vase period was probably due to growth of microbes and vascular blockage suggesting that adding a suitable germicide in vase solution can prevent the growth of microbes and can increase water uptake as confirmed by Anjum et al. (2001). Hashemabadi et al. (2015) demonstrated that enhancement of vase life can be described with antimicrobial properties of the mentioned above compounds, so that water absorption improved with prevention of vascular blockage and it delays water deficiency related wilting and reported that antiethylene compounds and also antibiotics increase water absorption, significantly. 
Table (3). Effect of some preservative solutions on water uptake (g) of Gladiolus cut flowers "Rose Supreme" in the first experiment (April, 2015).

\begin{tabular}{|c|c|c|c|c|c|c|}
\hline \multicolumn{7}{|c|}{ water uptake (g) (April, 2015) } \\
\hline \multirow[b]{2}{*}{ Treatments } & \multicolumn{6}{|c|}{$\begin{array}{ll}\text { Vase Life (Days) } \\
\end{array}$} \\
\hline & $\begin{array}{c}\text { Initial } \\
\text { Time }\end{array}$ & 5 & 10 & 15 & 20 & Average \\
\hline Control & $30.01 \mathrm{e}$ & $58.91 d$ & $50.66 d$ & $40.26 e$ & $16.64 d$ & $39.30 \mathrm{e}$ \\
\hline Glutamic acid 100 mg/l & $32.13 d$ & $61.88 \mathrm{bc}$ & $54.37 \mathrm{bc}$ & $42.21 \mathrm{bcd}$ & $18.43 b c$ & $41.80 \mathrm{~cd}$ \\
\hline Glutamic acid $200 \mathrm{mg} / \mathrm{l}$ & $32.26 \mathrm{~cd}$ & $62.07 \mathrm{bc}$ & $54.96 \mathrm{bc}$ & $42.51 \mathrm{bcd}$ & $19.25 b$ & $42.21 \mathrm{~cd}$ \\
\hline Glutamic acid 300 mg/l & $33.65 a$ & $65.00 \mathrm{a}$ & $55.98 a b$ & $45.53 a$ & $20.87 a$ & $44.21 \mathrm{a}$ \\
\hline Salicylic acid 200 mg/l & $32.31 \mathrm{~cd}$ & $62.93 b$ & $57.03 a$ & 42.17bcd & $19.04 \mathrm{bc}$ & $42.70 \mathrm{~cd}$ \\
\hline Salicylic acid $400 \mathrm{mg} / \mathrm{l}$ & $33.15 a b c$ & $65.02 \mathrm{a}$ & $56.16 a b$ & $45.66 \mathrm{a}$ & 20. $60 a$ & $44.12 \mathrm{ab}$ \\
\hline Salicylic acid 600 mg/l & $32.51 \mathrm{bcd}$ & $61.37 \mathrm{bc}$ & $53.36 \mathrm{c}$ & 40.82de & $18.60 \mathrm{bc}$ & 41.33d \\
\hline Calcium chloride $1000 \mathrm{mg} / \mathrm{l}$ & $31.96 \mathrm{~d}$ & $62.12 \mathrm{bc}$ & $53.59 c$ & $41.74 \mathrm{cde}$ & $18.25 c$ & $41.5 \mathrm{~cd}$ \\
\hline Calcium chloride $2000 \mathrm{mg} / \mathrm{l}$ & $32.15 d$ & $61.13 \mathrm{bc}$ & $54.64 b c$ & $41.79 \mathrm{cde}$ & $18.51 \mathrm{bc}$ & $41.33 c d$ \\
\hline Calcium chloride $3000 \mathrm{mg} / \mathrm{l}$ & 33.14abc & $62.79 \mathrm{~b}$ & $55.58 a b$ & $43.39 \mathrm{bc}$ & $18.86 \mathrm{bc}$ & 42.75bcd \\
\hline Aluminum sulphate $100 \mathrm{mg} / \mathrm{l}$ & $32.06 \mathrm{~d}$ & $60.76 \mathrm{~cd}$ & $54.65 \mathrm{bc}$ & 42.13bcd & $18.29 c$ & $41.58 \mathrm{~cd}$ \\
\hline Aluminum sulphate $200 \mathrm{mg} / \mathrm{l}$ & $32.02 d$ & $61.9 b c$ & $53.51 \mathrm{c}$ & $43.41 b c$ & $18.76 \mathrm{bc}$ & $41.92 \mathrm{~cd}$ \\
\hline Aluminum sulphate $300 \mathrm{mg} / \mathrm{l}$ & $33.28 a b$ & $62.62 \mathrm{bc}$ & $55.22 \mathrm{abc}$ & $43.65 b$ & $19.02 b c$ & $42.76 \mathrm{bc}$ \\
\hline Average & 32.36d & $62.19 a$ & $54.60 \mathrm{~b}$ & 42.72c & $18.86 \mathrm{e}$ & 42.14 \\
\hline \multirow[t]{2}{*}{ LSD at 0.05} & \multicolumn{2}{|r|}{ T: 1.42} & \multicolumn{2}{|c|}{ D: 0.88} & T×D: 3.21 & \\
\hline & ents & D: Vase Li & \multicolumn{2}{|c|}{ T×D: Interaction } & & \\
\hline
\end{tabular}

Table (4). Effect of some preservative solutions on water uptake (g) of Gladiolus cut flowers "Rose Supreme" in the second experiment (November, 2015).

\begin{tabular}{|c|c|c|c|c|c|c|}
\hline \multicolumn{7}{|c|}{ water uptake (g) (November, 2015) } \\
\hline \multirow[b]{2}{*}{ Treatments } & \multicolumn{6}{|c|}{\begin{tabular}{|l} 
Vase Life (Days) \\
\end{tabular}} \\
\hline & $\begin{array}{c}\text { Initial } \\
\text { Time }\end{array}$ & 5 & 10 & 15 & 20 & Average \\
\hline Control & $27.07 f$ & $64.03 d$ & $42.24 \mathrm{e}$ & $28.10 d$ & $18.57 \mathrm{e}$ & $36.00 f$ \\
\hline Glutamic acid $100 \mathrm{mg} / \mathrm{l}$ & $28.24 \mathrm{cde}$ & $65.78 \mathrm{~cd}$ & $45.83 \mathrm{bc}$ & $29.71 \mathrm{c}$ & $19.20 \mathrm{de}$ & 37.75de \\
\hline Glutamic acid 200 mg/l & $28.48 b c$ & $66.15 \mathrm{~cd}$ & $45.47 \mathrm{~cd}$ & $30.00 \mathrm{c}$ & $19.86 \mathrm{~cd}$ & $37.99 \mathrm{~cd}$ \\
\hline Glutamic acid $300 \mathrm{mg} / \mathrm{l}$ & $29.21 \mathrm{a}$ & $70.77 \mathrm{a}$ & $48.62 \mathrm{a}$ & $32.58 a$ & $21.31 \mathrm{a}$ & $40.49 a$ \\
\hline Salicylic acid 200 mg/l & $28.25 \mathrm{cde}$ & $67.14 \mathrm{bc}$ & $45.43 \mathrm{~cd}$ & $29.58 \mathrm{c}$ & $19.09 \mathrm{de}$ & $37.90 \mathrm{cde}$ \\
\hline Salicylic acid $400 \mathrm{mg} / \mathrm{l}$ & $29.21 \mathrm{a}$ & $71.26 \mathrm{a}$ & $48.41 \mathrm{a}$ & $32.6 a$ & $21.05 a b$ & $40.51 a$ \\
\hline Salicylic acid 600 mg/l & $28.44 \mathrm{bcd}$ & $65.08 \mathrm{~cd}$ & 43.64de & $29.70 c$ & $18.84 \mathrm{e}$ & $37.14 \mathrm{e}$ \\
\hline Calcium chloride 1000 mg/l & $27.99 \mathrm{e}$ & $66.65 b c$ & $44.01 \mathrm{cde}$ & $29.54 \mathrm{c}$ & $19.01 \mathrm{de}$ & 37.44de \\
\hline Calcium chloride 2000 mg/l & 28.20 cde & $66.47 c$ & $45.52 \mathrm{~cd}$ & $30.07 \mathrm{c}$ & $19.45 \mathrm{cde}$ & $37.94 \mathrm{cde}$ \\
\hline Calcium chloride 3000 mg/l & $28.78 b$ & $69.01 \mathrm{ab}$ & $47.55 a b$ & $31.25 b$ & $19.88 \mathrm{~cd}$ & $39.29 b$ \\
\hline Aluminum sulphate $100 \mathrm{mg} / \mathrm{l}$ & 28.04de & $65.33 \mathrm{~cd}$ & $44.63 \mathrm{~cd}$ & $29.60 \mathrm{c}$ & $19.29 \mathrm{de}$ & $37.38 \mathrm{de}$ \\
\hline Aluminum sulphate $200 \mathrm{mg} / \mathrm{l}$ & $28.52 b c$ & $65.95 \mathrm{~cd}$ & $45.22 \mathrm{~cd}$ & $29.90 c$ & $19.82 \mathrm{~cd}$ & $37.88 \mathrm{cde}$ \\
\hline Aluminum sulphate $300 \mathrm{mg} / \mathrm{l}$ & $28.82 a b$ & $67.03 \mathrm{bc}$ & $45.69 \mathrm{bc}$ & $31.12 b$ & $20.22 \mathrm{bc}$ & $38.58 b c$ \\
\hline Average & $28.40 d$ & $66.97 a$ & $45.56 b$ & $30.29 c$ & $19.66 \mathrm{e}$ & 38.18 \\
\hline \multirow[t]{2}{*}{ LSD at 0.05} & \multicolumn{2}{|c|}{$T: 0.81$} & \multicolumn{2}{|c|}{ D: 0.50} & \multirow{2}{*}{$T \times D: 1.83$} & \\
\hline & ents & : Vase Life & $T \times D$ & Interacti & & \\
\hline
\end{tabular}

\section{Total Chlorophyll (SPAD)}

Data of the present investigation, listed in Tables 5 and 6 showed that in both experiments (April and November, 2015), all treatments caused delay in degradation of total chlorophyll and preserved total chlorophyll content 
compared with the control. Moreover, statistical analysis of these data proved that the most significant increase in chlorophyll leaf content than other treatments was recorded by treatment of glutamic acid $(300 \mathrm{mg} / \mathrm{l})$, salicylic acid (400 mg/l), calcium chloride (3000 mg/l) and aluminum sulphate $(300 \mathrm{mg} / \mathrm{l})$. On the other hand, our data in the first experiment (April, 2015) revealed that the change in total chlorophyll content of Gladiolus cut flowers was increased with increasing vase life periods.

We could attribute the delay of chlorophyll degradation in flowers which pulsed in glutamic acid to its action on inhibiting ACC-oxidase activity (Aminocyclo propane carboxylate oxidase) that is the direct precursor of ethylene and decrease ROS (reactive oxygen species) with increase enzyme antioxidant activity decrease number of bacteria and ACC-oxidase activity (Kazemi and Ameri, 2012a). These results were found in agreement with those of Kazemi et al. (2012a) and are in accordance with those of Kazemi and Ameri (2012a) on Carnation. Similarly, Zamani et al. (2011) on Rose cut flowers.

Likewise, results of salicylic acid were found in accordance to those of Bayat et al. (2011) and Kazemi et al. (2012c) on Carnation cut flowers and Mohammadi et al. (2014) on Gladiolus cut flowers. The effect of salicylic acid might be due to the effect of salicylic acid that affect postharvest life of cut flowers probably via the declining bacterial growth, reducing vascular blockage, reducing transpiration, preventing ethylene formation and inducing antioxidant system in treated cut flowers thereby delaying the senescence process as reported by Danaee et al. (2013).

With respect to calcium chloride, results were found in conformity with those of Abdolmaleki et al. (2015) on Rose and Zadeh and Mirzakhani (2012) on Carnation, they indicated that calcium chloride have significantly increased chlorophyll content in leaves. These results may due to the important role in increasing tissue resistance and delaying senility through preventing ethylene synthesis and its processing as found by Zadeh and Mirzakhani (2012) and Cortes et al. (2011). On the other hand, this salt is already known to lower the respiration as confirmed by Anjum et al. (2001). In addition, the calcium ion also seems to affect ethylene action on cell membranes by inhibiting ion leakage and reducing the effect of ethylene on senescence as proved by Asfanani et al. (2008).

Effectiveness of aluminum sulphate on delaying the degradation of chlorophyll might be referred to the role of aluminum sulphate as a microbial inhibitor, reducing the transpiration rate and stimulate the minimum ethylene production as reported by Hashemabadi et al. (2015), Mohammadi et al. (2012) and Tsegaw et al. (2011). They are in harmony with findings of Jowker et al. (2012) and Hajizadeh et al. (2012) on Rose, they stated that aluminum sulphate lead to a considerable delay in degradation of chlorophyll compared to control.

On the other hand, present data in the first experiment (April, 2015) revealed that the change in total chlorophyll content of Gladiolus cut flowers was increased with increasing vase life periods and the differences among all 
tested vase life periods were statistically significant, except for the last three dates of sampling (10,15 and 20 days) where the difference was significantly decreased compared with initial time, while the data showed a significant increase in chlorophyll content with increasing periods of the life of flowers of Gladiolus cut flowers in the second experiment (November, 2015). Moreover, there were significant differences between all tested stages of vase life, except for the latest stage (20 days) which decreased compared with initial time. The greatest value in chlorophyll content was obtained by $5^{\text {th }}$ day compared to 0 day and $20^{\text {th }}$ day in both experiments of Gladiolus $\left(10^{\text {th }}\right.$ and $15^{\text {th }}$ day in first experiment). Leaf yellowing is a form of senescence caused by an internal hormone imbalance, such as a lack of cytokinins as confirmed by Ferrante et al. (2004). The maintenance of green color in the leaves is an important quality propertys in these economically significant ornamental plants. Previous study had revealed that the leaf yellowing of cut flowers is associated with chlorophyll breakdown and loss, thereby decreasing significant vase life Jahanbazi et al. (2014).

Table (5). Effect of some preservative solutions on chlorophyll index (SPAD) of Gladiolus cut flowers "Rose Supreme" in the first experiment (April, 2015).

\begin{tabular}{|c|c|c|c|c|c|c|}
\hline \multicolumn{7}{|c|}{ Chlorophyll index (SPAD) (April, 2015) } \\
\hline \multirow[b]{2}{*}{ Treatments } & \multicolumn{6}{|c|}{ Vase Life (Days) } \\
\hline & $\begin{array}{l}\text { Initial } \\
\text { Time }\end{array}$ & 5 & 10 & 15 & 20 & Average \\
\hline Control & $46.63 \mathrm{c}$ & $48.43 f$ & $46.01 d$ & $42.91 \mathrm{c}$ & $40.01 \mathrm{e}$ & $44.80 f$ \\
\hline Glutamic acid 100 mg/l & $47.96 \mathrm{~b}$ & $50.43 \mathrm{cde}$ & $48.22 \mathrm{c}$ & $44.73 b c$ & $42.89 \mathrm{~cd}$ & 46.85de \\
\hline Glutamic acid 200 mg/l & $48.58 \mathrm{~b}$ & $50.67 \mathrm{bcde}$ & $48.58 \mathrm{c}$ & $45.04 a b$ & $43.41 \mathrm{~cd}$ & $47.26 \mathrm{de}$ \\
\hline Glutamic acid 300 mg/l & $51.56 a$ & $52.63 a$ & $50.17 a$ & $48.54 a$ & $45.9 a$ & $49.75 a$ \\
\hline Salicylic acid 200 mg/l & $48.08 \mathrm{~b}$ & $50.96 \mathrm{bc}$ & $48.49 \mathrm{c}$ & $44.82 \mathrm{bc}$ & $43.49 \mathrm{~cd}$ & 47.17de \\
\hline Salicylic acid 400 mg/l & $51.19 a$ & $52.93 a$ & $49.88 a b$ & $48.49 a$ & 46.12 & $49.72 a$ \\
\hline Salicylic acid $600 \mathrm{mg} / \mathrm{l}$ & $50.38 a$ & $50.81 \mathrm{bcd}$ & $48.59 \mathrm{c}$ & $44.39 b c$ & $42.58 \mathrm{~cd}$ & $47.35 \mathrm{cde}$ \\
\hline Calcium chloride 1000 mg/l & $48.26 \mathrm{~b}$ & $49.97 e$ & $48.35 \mathrm{c}$ & $43.83 \mathrm{bc}$ & $42.92 \mathrm{~cd}$ & 46.67de \\
\hline Calcium chloride 2000 mg/l & $48.58 \mathrm{~b}$ & $50.68 \mathrm{bcde}$ & $48.36 \mathrm{c}$ & $43.98 \mathrm{bc}$ & $43.36 \mathrm{~cd}$ & 46.99de \\
\hline Calcium chloride $3000 \mathrm{mg} / \mathrm{l}$ & $50.83 a$ & $51.27 \mathrm{~b}$ & $48.83 \mathrm{c}$ & $45.02 b c$ & $44.17 \mathrm{c}$ & $48.02 b c$ \\
\hline $\begin{array}{l}\text { Aluminum sulphate } 100 \\
\mathrm{mg} / \mathrm{l}\end{array}$ & $48.03 b$ & $50.07 \mathrm{de}$ & $48.51 \mathrm{c}$ & $44.62 \mathrm{bc}$ & $41.97 d$ & $46.64 e$ \\
\hline $\begin{array}{l}\text { Aluminum sulphate } 200 \\
\mathrm{mg} / \mathrm{l}\end{array}$ & $48.62 b$ & $50.97 \mathrm{bc}$ & $48.86 \mathrm{bc}$ & $45.72 b$ & $42.80 \mathrm{~cd}$ & $47.39 \mathrm{~cd}$ \\
\hline $\begin{array}{l}\text { Aluminum sulphate } 300 \\
\mathrm{mg} / \mathrm{l}\end{array}$ & $50.36 a$ & $51.45 b$ & $49.02 b c$ & $46.04 a b$ & $44.22 \mathrm{bc}$ & $48.22 b$ \\
\hline Average & $49.16 b$ & $50.87 a$ & $48.60 \mathrm{c}$ & $45.24 d$ & $43.37 \mathrm{e}$ & 47.45 \\
\hline LSD at 0.05 & \multicolumn{2}{|c|}{ T: 0.74} & \multicolumn{2}{|c|}{ D: 0.46} & \multicolumn{2}{|c|}{$T \times D: 1.67$} \\
\hline \multicolumn{2}{|c|}{ T: Treatments } & D: Vase Life & \multicolumn{3}{|c|}{$\mathrm{T} \times \mathrm{D}$ : Interaction } & \\
\hline
\end{tabular}


Table (6). Effect of some preservative solutions on chlorophyll index (SPAD) of Gladiolus cut flowers "Rose Supreme" in the second experiment (November, 2015).

\begin{tabular}{|c|c|c|c|c|c|c|}
\hline \multicolumn{7}{|c|}{ Chlorophyll index (SPAD) (November, 2015) } \\
\hline \multirow[b]{2}{*}{ Treatments } & \multicolumn{6}{|c|}{ Vase Life (Days) } \\
\hline & $\begin{array}{c}\text { Initial } \\
\text { Time }\end{array}$ & 5 & 10 & 15 & 20 & Average \\
\hline Control & $48.94 f$ & $61.04 f$ & $57.93 \mathrm{c}$ & $51.04 \mathrm{c}$ & $48.18 d$ & $53.43 \mathrm{~g}$ \\
\hline Glutamic acid 100 mg/l & 49.85de & 62.87def & $60.48 b$ & $54.11 b$ & $48.74 d$ & $55.21 f$ \\
\hline Glutamic acid 200 mg/l & $50.21 \mathrm{bcd}$ & 63.44de & $60.54 b$ & $55.65 a b$ & $49.09 \mathrm{bcd}$ & 55.79def \\
\hline Glutamic acid $300 \mathrm{mg} / \mathrm{l}$ & $51.00 \mathrm{a}$ & $67.30 \mathrm{a}$ & $64.33 a$ & $56.81 a$ & $51.51 \mathrm{a}$ & $58.19 a$ \\
\hline Salicylic acid 200 mg/l & $50.02 \mathrm{cde}$ & $63.66 \mathrm{cde}$ & $60.21 b c$ & $55.3 a b$ & $49.01 \mathrm{bcd}$ & 55.64def \\
\hline Salicylic acid 400 mg/l & $50.97 a$ & $66.99 a$ & $64.19 a$ & $55.12 a b$ & $51.13 a$ & $57.68 \mathrm{ab}$ \\
\hline Salicylic acid 600 mg/l & $50.10 \mathrm{~cd}$ & $63.11 \mathrm{de}$ & $60.12 b c$ & $55.55 a b$ & $49.14 \mathrm{bcd}$ & $55.60 \mathrm{def}$ \\
\hline Calcium chloride $1000 \mathrm{mg} / \mathrm{l}$ & $49.51 \mathrm{e}$ & 63.81 cde & $60.33 b$ & $53.90 \mathrm{~b}$ & $48.34 d$ & $55.18 f$ \\
\hline Calcium chloride $2000 \mathrm{mg} / \mathrm{l}$ & 49.68de & $65.52 a b c$ & $60.93 b$ & $55.75 a b$ & $48.98 \mathrm{~cd}$ & $56.17 \mathrm{cde}$ \\
\hline Calcium chloride $3000 \mathrm{mg} / \mathrm{l}$ & $50.50 \mathrm{abc}$ & $66.12 a b$ & $61.81 b$ & $56.66 a$ & $49.87 \mathrm{bc}$ & $56.99 b c$ \\
\hline Aluminum sulphate $100 \mathrm{mg} / \mathrm{l}$ & 49.91de & $62.58 \mathrm{ef}$ & $59.92 b c$ & $55.58 a b$ & $48.82 d$ & $55.36 \mathrm{ef}$ \\
\hline Aluminum sulphate $200 \mathrm{mg} / \mathrm{l}$ & 49.95de & $64.46 \mathrm{bcde}$ & $60.79 b$ & $55.78 a b$ & $48.78 d$ & $55.95 \mathrm{def}$ \\
\hline Aluminum sulphate $300 \mathrm{mg} / \mathrm{l}$ & $50.73 a b$ & $64.54 \mathrm{bcd}$ & $59.67 \mathrm{bc}$ & $56.52 a$ & $50.00 \mathrm{~b}$ & $56.29 \mathrm{~cd}$ \\
\hline Average & $50.11 d$ & $64.27 a$ & $60.87 \mathrm{~b}$ & $55.21 \mathrm{c}$ & $49.35 \mathrm{e}$ & 55.96 \\
\hline LSD at 0.05 & \multicolumn{2}{|c|}{$\mathrm{T}: 0.88$} & \multicolumn{2}{|c|}{ D: 0.55} & \multicolumn{2}{|l|}{ T×D: 1.99} \\
\hline
\end{tabular}

\section{Determination of Proline ( $\mu \mathrm{g}$ proline/g)}

The effect of some preservative solutions on accumulation of proline in leaves of Gladiolus cut flowers in both experiments (April and November, 2015) are presented in Table (7). It has been found that all studied materials had remarkable significant effect on decreasing accumulation of proline compared to control in both experiments. Except for glutamic acid at (100 and $200 \mathrm{mg} / \mathrm{l})$, the last concentration of salicylic acid (600 mg/l) and calcium chloride at (1000 and $2000 \mathrm{mg} / \mathrm{l}$ ) which did not show significant differences in comparison with control in the first experiment. Moreover, there were no significant differences between the other treatments, except the differences between intermediate level of aluminum sulphate $(200 \mathrm{mg} / \mathrm{l})$ compared to the first level of aluminum sulphate $(100 \mathrm{mg} / \mathrm{l})$ in the first experiment. While, the greatest effect on decreasing accumulation of proline was recorded by the higher concentration of glutamic acid $(300 \mathrm{mg} / \mathrm{l})$ in the second experiment.

Similar results were found by Kazemi et al. (2012c) on Carnation, they showed that glutamic acid decrease proline accumulation significantly. These effect of glutamic acid might be referred to the decreases in ACO activity (Aminocyclo propane carboxylate oxidase that is the direct precursor of ethylene as confirmed by Kazemi et al. (2012a). We could return the effect of 
salicylic acid to improving the antioxidant system and reducing oxidative stress damages during flower senescence as observed by Gerallio and Ghasemnezhad (2011). In addition the inhibition of ethylene biosynthesis and prolong vase life (Marandi et al., 2011). These result are in conformity with those of Kazemi and Shokri (2011) on Lisianthus flowers.

Furthermore, the significant effect of calcium chloride is in agreement with Ibrahim et al. (2011) on Gerbera and Zadeh and Mirzakhani (2012) on Carnation. They showed that calcium chloride improved vase life and leaf quality. These effectiveness might be related to calcium chloride ability to inhibit the synthesis or action of ethylene. In addition, its role of increase tissue resistance and lower the rate of respiration as proved by Cortes et al. (2011) and Anjum et al. (2001). Regarding the effect of aluminum sulphate, results are similar to those of El-Quesni et al. (2012) on Schefflera, they found that aluminum sulphate increased vase life and quality. May be this results due to its action as an antimicrobial agent in the solution Hussen and Yassin (2013) and Mohammadi et al. (2012) Jowker et al. (2012) they found that aluminum sulphate improved postharvest visual quality by retaining leave freshness even at the end of vase life.

\section{Number of Bacteria (CFU /ml)}

The effect of some preservative solutions on the number of bacteria of Gladiolus cut flowers "Rose Supreme" in first and second experiment (April and November, 2015), are shown in Table (7), proved that number of bacteria in vase solution decreased significantly by using all studied materials compared to control. Moreover, the best effect on decreasing number of bacteria was obtained by glutamic acid at $(300 \mathrm{mg} / \mathrm{l})$, salicylic acid at (400 and $600 \mathrm{mg} / \mathrm{l})$, calcium chloride at $(3000 \mathrm{mg} / \mathrm{l})$ and all concentrations of aluminum sulphate $(100,200$ and $300 \mathrm{mg} / \mathrm{l})$ in the first experiment. Whilst glutamic acid at $300 \mathrm{mg} / \mathrm{l}$ resulted in the greatest effect on decrease number of bacteria in vase solution of Gladiolus cut flowers in the second experiment.

The positive effect of glutamic acid may be that glutamic acid is readily metabolized by plants but not by many microorganisms, so it considered to using it as a possible substitute for sucrose according to Aran et al. (2011) and Kazemi and Ameri (2012a). Similar results were obtained by Kazemi et al. (2012c) on Carnation cut flowers, who found that glutamic acid decreased microbial population on vase solution significantly. As for main effect of salicylic acid, results are in accordance with those of Kazemi and Ameri (2012a) and Kazemi et al. (2012c) on Carnation. They observed a significant effect of salicylic acid on bacterial population. Effectiveness of salicylic acid might be referred to its ability to decrease $\mathrm{pH}$ of vase solution which reduce the growth and proliferation of bacteria as confirmed by Soleimany-Fard et al. (2013).

On the other hand, the best effect on decreasing the number of bacteria by calcium chloride may be attributed to the absence of a carbon source which inhibited bacterial growth as proved by Cortes et al. (2011). These results are in harmony with those of Hashemabadi et al. (2015) on Carnation cut flowers who reported that anti-ethylene compounds and also antibiotics increase water absorption, significantly. The significant control on number of bacteria that 
obtained in aluminum sulphate pulsed flower stems may be related to not only limited to lowering the $\mathrm{pH}$ of vase solution but also Its effect is based at least in part, on its action as an antimicrobial agent in the solution (Hussen and Yassin 2013). These results are in agreement with those of Jowker et al. (2012) on Rose cut flowers who showed that aluminum sulphate inhibited microbial proliferation in vase solution.

\section{Vase Life (Day)}

Data presented in Table (7) cleared the effect of some preservative solutions on vase life of Gladiolus cut flowers "Rose Supreme" in first and second experiment (April and November, 2015). It has been proved from our results that, in general the four compounds which used in the two experiments showed positive effect on increasing vase life of Gladiolus cut flowers in comparison with control in both experiments. On the other hand, the last concentration of glutamic acid at $(300 \mathrm{mg} / \mathrm{l})$ and the intermediate concentration of salicylic acid (400 $\mathrm{mg} / \mathrm{l})$ resulted in the highest increase in the vase life in first experiment. Whereas, the best effect was found in glutamic acid at (200 and $300 \mathrm{mg} / \mathrm{l})$, salicylic acid at (400 mg/l) and aluminum sulphate at (200 and 300 $\mathrm{mg} / \mathrm{l})$ in the second experiment.

With respect to glutamic acid effects, results are similar to the findings of Kazemi et al. (2012) on Carnation cut flowers, Kazemi et al. (2012a) on Gerbera and Zamani et al. (2011) on Rose. They showed that treatments of glutamine significantly increased vase life and delayed flower senescence compared distilled water (control). These enhancement on vase life duration may be due to glutamic acid ability to control microbial contamination, so that improved water absorption, prevented vascular blockage and delayed water deficiency related wilting and control ethylene production that extend vase life of cut flowers (Hashemabadi et al., 2015). Similarly, Zamani et al. (2011) on Rose. Further, Kazemi and Ameri (2012a) stated that all glutamine concentrations prolonged Carnation vase life, while decreasing accumulation of bacteria in vase solution and ACC- oxidase activity (Aminocyclo propane carboxylate oxidase). Furthermore it has been proved that the observed decrease in ACC activity could be at least one mechanism through which relatively has affected on the senescence process (Aran et al., 2011).

These significant increase in vase life may be due to that salicylic acid (SA), a natural phenolic secondary metabolite, in various aspects of vital processes like ethylene biosynthesis, stomatal conductance, respiration, senescence and the activation of defense systems against different pathogens is well An and Mou (2011). SA treatments were effective to affect postharvest life of cut flowers probably via the declined bacterial growth, reduced vascular blockage, reduced transpiration, prevented ethylene formation and induced antioxidant system in treated cut flowers thereby delaying the senescence process confirmed by Danaee et al. (2013). These results are in accordance with those of Roodbaraky et al. (2012), Kazemi et al. (2012) on Carnation and Soleimany-Fard et al. (2013) on Alstroemeria flowers. They indicated that salicylic acid increased the vase life of cut flowers compared to control. 
The improving effect of calcium chloride on vase life might be attributed to possibility of calcium to decrease the respiration rate, osmotic adjustment and stability of cell membrane and increase water flow through the stems by association with pectin in the xylem cell walls, also calcium play important role in increasing tissue resistance and delaying senility through preventing ethylene synthesis and it's processing as confirmed by Sardoei (2014). Similar results were obtained by Amiri et al. (2009) and Ibrahim et al. (2011) on Gerbera, Zadeh and Mirzakhani (2012) on Carnation, Cortes et al. (2011), Abdolmaleki et al. (2015) on Rose and Seyedi et al. (2013) on Lilium cut flowers, they proved that treatments with calcium chloride increased longevity of cut flowers to highest values and delayed senescence.

We could return the effect of aluminum sulphate on increasing vase life of cut flowers to the antimicrobial effect, increase water uptake, inhibit ethylene production and action and reduce transpiration rate as reported by seyf et al. (2012);Mohammadi et al. (2012); Jowkar et al. (2012) and Hashemabadi et al. (2015).These results in agreement with those of Jowkar et al. (2012); seyf et al. (2012), Basaki et al. (2013) and Nader et al. (2015) on Rose, Hashemabadi et al. (2015) on Carnation, Mohammadi et al. (2014) on Tuberose and Amiri et al. (2009) on Gerbera cut flowers. They showed that the effect of aluminum sulphate on life of flower was significant.

During senescence, marked changes occur in the biochemical and biophysical properties of the cell membranes. Ethylene plays a central role in the senescence of many cut flowers as proved by Reid (1989). Flower vase life is affected by respiration, carbohydrates deterioration, disease inoculation, water uptake etc. During vase life of cut flowers, ethylene synthesis plays a major role in senescence. Similarly carbohydrates and soluble sugars in the petals also help in quality retention of cut flowers for longer period proved by Hussen and Yassin (2013). There was a direct relationship between vase life and, increasing of relative fresh weight and water uptake. Obstruction of the xylem by bacteria, therefore, inability of water absorption by flower steams is one of the current problems that lead to decrease in flowers postharvest longevity and also early wilting of them as observed by Sardoei (2014).Various studies have found that bacterial contamination is one of the most important factors in reducing postharvest life of cut flowers with the negative impact on respiration, photosynthesis and water uptake, also with increasing the evaporation, caused water imbalance and indirectly stimulates ethylene production and shortens postharvest life of cut flowers found by Mohammadi et al. (2012). According to the scientific findings, the postharvest life of different ornamental cut flowers could be affected by the application of various chemicals as preservatives as reported by Danaee et al. (2013). Anti-ethylene and antimicrobial compounds due to their stem end bacterial contamination control, can stimulate ethylene production indirectly and can control ethylene production and extending vase life of cut flowers confirmed by Hashemabadi et al. (2015). 
Table (7). Effect of some preservative solutions on proline ( $\mu \mathrm{g}$ proline/g), number of bacteria (CFU, Colony Forming Unit) and vase life (days) of Gladiolus cut flowers "Rose Supreme" in the first and the second experiments (April and November, 2015).

\begin{tabular}{|c|c|c|c|c|c|c|}
\hline \multirow[b]{2}{*}{ Treatments } & \multicolumn{3}{|c|}{ First experiment (April, 2015) } & \multicolumn{3}{|c|}{$\begin{array}{c}\text { Second experiment } \\
\text { (November, 2015) }\end{array}$} \\
\hline & $\begin{array}{l}\text { Proline } \\
\mu \mathrm{g} \\
\text { proline/g }\end{array}$ & $\begin{array}{c}\text { Number } \\
\text { of } \\
\text { bacteria } \\
\text { Log } 7 \\
\text { CFU } / \mathrm{ml}\end{array}$ & $\begin{array}{l}\text { Vase } \\
\text { life } \\
\text { (days) }\end{array}$ & $\begin{array}{l}\text { Proline } \\
\mu \mathrm{\mu g} \\
\text { proline/g }\end{array}$ & $\begin{array}{c}\text { Number } \\
\text { of } \\
\text { bacteria } \\
\text { Log } 7 \\
\text { CFU/ ml }\end{array}$ & $\begin{array}{l}\text { Vase } \\
\text { life } \\
\text { (days) }\end{array}$ \\
\hline Control & $943.3 a$ & $20.5 a$ & $14.92 d$ & $426.66 a$ & $11 \mathrm{a}$ & $17.5 d$ \\
\hline Glutamic acid 100 mg/l & $708.5 a b$ & $6.33 \mathrm{bcd}$ & $19.67 \mathrm{bc}$ & $186.86 \mathrm{e}$ & $7.67 \mathrm{c}$ & $21.58 \mathrm{~b}$ \\
\hline Glutamic acid 200 mg/l & $688.3 a b$ & $7.33 \mathrm{bc}$ & $20.42 b$ & $264.72 c$ & $5 d$ & $22.25 a b$ \\
\hline Glutamic acid 300 mg/l & $190.4 \mathrm{~cd}$ & 5 cde & $22.17 \mathrm{a}$ & $54.50 \mathrm{i}$ & $3 e$ & $23.17 a$ \\
\hline Salicylic acid 200 mg/l & $349.3 \mathrm{~cd}$ & $6.33 \mathrm{bcd}$ & $20.58 b$ & $147.93 \mathrm{gh}$ & $8.33 b c$ & $19.42 \mathrm{c}$ \\
\hline Salicylic acid 400 mg/l & $209.0 \mathrm{~cd}$ & 3.67def & $22.17 \mathrm{a}$ & $367.49 b$ & $5.33 d$ & $22.67 a b$ \\
\hline Salicylic acid 600 mg/l & $928.1 \mathrm{a}$ & $4 \mathrm{def}$ & $19.75 b c$ & $264.72 c$ & $6 d$ & $19.35 c$ \\
\hline Calcium chloride $1000 \mathrm{mg} / \mathrm{l}$ & $817.5 a$ & $8 b$ & $18.5 \mathrm{c}$ & $362.82 b$ & $9.67 a b$ & $19.42 \mathrm{c}$ \\
\hline Calcium chloride $2000 \mathrm{mg} / \mathrm{l}$ & $915.5 a$ & $7 \mathrm{bc}$ & $18.83 c$ & $266.27 c$ & $8.67 b c$ & $20.08 \mathrm{c}$ \\
\hline Calcium chloride $3000 \mathrm{mg} / \mathrm{l}$ & $301.5 \mathrm{~cd}$ & $4.67 \mathrm{cde}$ & $19.42 \mathrm{bc}$ & $152.60 f$ & $8 c$ & $20.25 c$ \\
\hline Aluminum sulphate $100 \mathrm{mg} / \mathrm{l}$ & $479.6 \mathrm{bc}$ & $2.67 \mathrm{ef}$ & $19.17 \mathrm{bc}$ & $214.89 d$ & $9 b c$ & $19.75 c$ \\
\hline Aluminum sulphate $200 \mathrm{mg} / \mathrm{l}$ & $129.9 d$ & $2.33 \mathrm{ef}$ & $19.92 \mathrm{bc}$ & $130.80 \mathrm{gh}$ & $7.67 \mathrm{c}$ & $21.5 b$ \\
\hline Aluminum sulphate $300 \mathrm{mg} / \mathrm{l}$ & $360.2 \mathrm{~cd}$ & $1.33 f$ & $20.58 b$ & $115.23 \mathrm{~h}$ & $5.67 d$ & $22.17 a b$ \\
\hline LSD at 0.05 & 303.44 & 2.83 & 1.43 & 17.29 & 1.40 & 1.17 \\
\hline
\end{tabular}

\section{CONCLUSION}

In conclusion, the present study demonstrates that all treatments showed significant effect on quality parameters and flowers longevity compared to control in Gladiolus experiments. Glutamic acid with last concentration (300 $\mathrm{mg} / \mathrm{l})$ and intermediate concentration of salicylic acid $(400 \mathrm{mg} / \mathrm{l})$ were more effective on increasing vase life compared to control than other treatments in both experiments, except for treatments of glutamic acid $(200 \mathrm{mg} / \mathrm{l})$ and aluminum sulphate $(200$ and $300 \mathrm{mg} / \mathrm{l})$ in second experiment. Our findings support for wider testing and use of the natural, cheap, safe and biodegradable compounds.

\section{REFERENCES}

Abdolmaleki, M., K. Morteza, E. Saeid and R. Asghar. (2015). Improvement in Vase Life of Cut Rose cv. "Dolce Vita" by Pre-harvest Foliar Application of Calcium Chloride and Salicylic Acid. International Journal of Hoticultural Science and Technology (IJHST), 6(2) 55-66.

Abo-Leila, B. A. and, R. A. Eid. (2011). Improving Gladiolus Growth, Flower Keeping Quality by Using Some Vitamins Application. Journal of American Science, 7(3):169-174. 
Adil, M., W. Ahmad, K. S. Ahmad, J. Shafi, M. A. Shehzad, M. A. Sarwar, M. Salman, M. I. Ghani and M. Iqabal. (2013). Effect of Different Planting Dates on Growth and Development of Gladiolus grandiflorus under the Ecological Conditions of Faisalabad, Pakistan. Universal Journal of Agricultural Research, 1(3):110-117.

Amiri, M.E., V. Rabiei and S.B. Zanjani. (2009). Influence of Pulse Chemical Treatments on Water Relation in Cut Gerbera (Gerbera jamesonii cv. Pags) Flowers. Journal of Food, Agriculture \& Environment, 7 (1): 182185.

An, F.C. and Z. Mou. (2011). Salicylic acid and its function in plant immunity. J Integr Plant Biol, 53 (6): 412-428.

Anjum, M. A., F. Naveed, F. Shakeel and S. Amin. (2001). Effect of Some Chemicals on Keeping Quality and Vase-Life of Tuberose (Polianthes Tuberosa L.) Cut Flowers. Journal of Research (Science), Bahauddin Zakariya University, Multan, Pakistan. 12(1): 01-07.

Aran, M., M. Kazemi and S. Zamani. (2011). Effects of Succinic Acid and Glutamine on ACC- Oxidase Activity, Microbe Population and Senescence of Carnation Cut Flowers. World Applied Science journal, 12(9):1616-1620.

Asfanani, M., G. H. Davarynejad and A. Tehranifar. (2008). Effects of Preharvest Calcium Fertilization on Vase Life of Rose Cut Flowers CV. Alexander. Acta. Hort., 804.

Ashtari, M., E. Hadavi and J. Hekmati. (2013). Application of Various Levels of Malic Acid and Salicylic Acid as Short-Term Treatments on Durability of Cut Rose cv. "Avalanche". Interl Jour.of Agri. Sci., 3(2): 100-104.

Badr, M., G. Gehan, F. Eman and M. El.Torky. (2008). Effect of Some Chemical and Natural Holding Solutions on the Postharvest Quality of Gladiolus spikes. Alex. J. Agric. Res., 53(3)45-50.

Barakat, A. A. (2013). Effect of cold storage duration harvesting stage and postharvest treatment on flower quality of Solidago Canadensis cv. "Tara". Unpublished PhD Thesis, Faculty of Agric., Alexandria University.

Basaki, T., S. Faraji, M. A. Nejat and M.H. Azimi.(2013). The Effect of Chemical Treatments on Cut Flower Longevity of Rosa Hybrid Cultivar Maroussia. International journal of Agronomy and Plant Production, 4 (3):450-453.

Bates, L., R.P. Waldren and I. D. Teare. (1973). Rapid Determination of Free Proline for Water-Stress Studies. Plant and Soil, 39, 205-207.

Bayat, H., M. Azizi, M. Shoor and N. Vahdati. (2011). J. Hortic. Sci., 25 (4): 384-390.

Cortes, M.H., A.A. Frias, S.G. Moreno, M.M. Piña, G.H.D.L.C. Guzmán and S.G. Sandoval, (2011). The effects of calcium on postharvestwater status and vase life of Rosa hybrida cv. grand gala. International Journal of Agriculture and Biology, 13: 233-238.

Danaee, E., R. Naderi, S. Kalatejari and A. R. L. Moghadam. (2013). Evaluation the effect salicylic acid and benzyl adenine on enzymic activities and longevity of gerbera cut flowers. International Research Journal of Applied and Basic Sciences, 7 (5): 304-308.

El-Quesni, F., E.M. Lobna, S. Taha and M.M. I. Soad. (2012). Effect of Some Chemical Preservative Solutions on Water Relation and Vase Life of 
Schefflera Arboricola Cut Foliage. Journal of Applied Sciences Research, 8(3): 1409-1414.

Farahat, M.M. and A. Gaber. (2009). Influence of preservative materials on postharvest performance of cut window leaf foliage (Monstera deliciosa). Acta Hort., 3: 1715-1718.

Ferrante, A., P. Vernieri, G. Serra and F. Tognoni. (2004).Changes in Abscisic Acid during Leaf Yellowing of Cut Stock Flowers. Plant Growth Regulation, 43(2): 127-134. (Abstrct).

Gendy, A.S. and A. A. Mahmoud. (2012). Effect of Some Preservative Solution Treatments on Characters of (Strelitzia reginae) Cut Flowers. Aust. J. Basic \& Appl. Sci., 6(5): 260-267.

Gerallio, S. and M. Ghasemnezhad. (2011). Effect of Salicylic Acid on Antioxidant Enzyme Activity and Petal Senescence in 'Yellow Island' Cut Rose Flowers. Journal of Fruit and Ornamental Plant Research, 19(1): 183-193.

Hajizadeh, H., S. A. Farokhzad and V.G. Chelan. (2012). Using of Preservative Solutions to Improve Postharvest Life of Rosa Hybrid cv. Black magic. Journal of Agricultural Technology, 8(5): 1801-1810.

Hashemabadi, D., B. Kaviani, A. Shirinpour and D. Yaghoobi. (2015). Response of Cut Carnation (Dianthus caryopyllus L.cv. Tempo) to Essential Oils and Antimicrobial Compounds. International Journal of Biosciences (IJB), 6 (3): 36-44.

Hussen, S. and H. Yassin. (2013). Review on the Impact of Different Vase Solutions on the Postharvest Life of Rose Flower. International Journal of Agricultural Research and Review, 1 (2): 13-17.

Ibrahim, S. M. M., L. S. Taha, and R. A. Eid. (2011). Extending Postharvest Life and Keeping Quality of Gerbera Cut-Flowers Using Some Chemical Preservatives. Journal of Applied Sciences Research, 7(7):1233-1239.

Jahanbazi, T., F. Mortezaienejad and M. Jafararpoor. (2014). Impact of Salicylic Acid and Jasmonic Acid on Keeping Quality of Rose (cv. 'Angelina') Flowers. Journal of Novel Applied Sciences, 3(11) 1328-1335.

Jowker, M. M., M. Kafi, A. Khaligi and N. Hasanzadeh. (2012). Evaluation of Aluminum Sulphate as Vase Solution Biocide on Postharvest Microbial and Physiological Properties of 'Cherry Brandy' Rose. Annals of Biological Research, 3(2): 1132-1144.

Kazemi, M and A. Ameri. (2012a). Response of Vase-life Carnation Cut Flower to Salicylic Acid, Silver Nanoparticles, Glutamine and Essential Oil. Asian J Animal Sci., 6(3): 122-131.

Kazemi, M. and K. Shokri. (2011). Role of Salicylic Acid in Decrease of Membrane Senescence in Cut Lisianthus Flowers. World Appl. Sci. J., 13(1): 142-146.

Kazemi, M., Aran M. and S. Zamani. (2011a). Effect of Some Treatment Chemicals on Keeping Quality and Vase Life of Gerbera Cut Flowers. American journal of plant physiology, 6(2) 99-105.

Kazemi, M., E. Hadavi and J. Hekmati. (2011c). Role of Salicylic Acid in Decreases of Membrane Senescence in Cut Carnation Flowers. Amer. J. Plant Physiology, 6:106-112.

Kazemi, M., E. Hadavi and J. Hekmati. (2012) .Effect of salicylic acid, malic acid, citric acid and sucrose on antioxidant activity, membrane stability 
and ACC-Oxidase activity(Aminocyclo propanecar boxylate oxidase) in relation to vase life of Carnation cut flowers . J. Plant Sci., 7(2): 78-84.

Kazemi, M., M. Aran and S. Zamani. (2011b). Interaction between Glutamine and Different Chemicals on Extending the Vase Life of Cut Flowers of 'Prato' Lily. American journal of plant physiology, 6(2) 120-125.

Kazemi, M., M. Gholami and F. Hassanvand. (2012a). Effects of Silicon on Antioxidative Deffense System and Membrane Lipid Peroxidation in Gerbera Cut Flower. Assian Journal of Biochemistry. ISSN 1815-9923.

Kazemi, M., M. Gholami, M. Asdi, S. Aghdasi and M. Almasi. (2012c). Response of Carnation (Dianthus caryophyllus L.) to Salicylic Acid and Glutamine. Asian. J .Biochem, 7(3):158-164.

Khan, W., B. Prithiviraj and D.L. Smith. (2003). Photosynthetic response of corn and soybean to foliar application of salicylates. J. Plant Physiol., 160: 485-492.

Khenizy, S. A. M., A. A. Zaky and Y. M.E. El-Shewaikh. (2013). Effect of Humic Acid on Vase Life of Gerbera Flowers after Cutting. Journal of Horticultural Science \& Ornamental Plants, 5 (2): 127-136.

Khimani, R. A., N. Thube and R. G. Jadav. (2005). Effect of Stem Length and Panicle Weight on Postharvest Quality in Golden Rod (Solidago canadensis Linn.). Journal of Ornamental Horticulture (New Series), 8(4): 287-289.

Liao, L.J., Y.H. Lin, K.L. Huang and W.S.h. Chen. (2001). Vase Life of Eustoma Grandiflorum as Affected by Aluminum sulfate. Botanical Bulletin of Academia Sinica, 42: 35- 38.

Marandi, J. R., A. Hassani, A. Abdollahi, and S. Hanafi. (2011). Improvement of the Vase Life of Cut Gladiolus Flowers by Essential Oils, Salicylic Acid and Silver Thiosulfate. J. Medicinal Plants Res., 5:5039-5043.

Marin, J.A., P. Andreu, A. Carrasco and A. Arbeloa. (2009). Prolina en Tejidosy Exudados de Raíz Como Respuesta al Estrés Salino de Cultivos de Raíces Aisladas de Patrones Frutales Del Género Prunus. ITEA-Información Técnica Económica Agraria, 105: 282-290.

Martin-Diana, A. B., D. Rico, J. M. Frias, J. M. Barat, G .T.M. Henehan and C. Barry-Rtan. (2007). Calcium for Extending the Shelf Life of Fresh Whole and Minimally Processed Fruits and Vegetables: a review. Trends in 300 Food Science \& Technology, 18:210-218.

Mashhadian, N. V., A. Tehranifar, H. Bayat, and Y. Selahvarzi. (2012). Salicylic and Citric Acid Treatments Improve the Vase Life of Cut Chrysanthemum Flowers. J. Agr. Sci. Tech., 14: 879-887.

Mazher, A. A. M., S. M. Zaghloul, S. A. Mohmoud and H.S. Siam. (2011). Stimulatory Effect of Kinetin, Ascorbic acid and Glutamic Acid on Growth and Chemical Constituents of Codiaeum variegatum L. Plants. AmericanEurasian J. Agric. \& Environ. Sci., 10 (3): 318-323.

Mohamed, E. A. (2015). Effects of Some Natural Components on the Vase Life of Rose Cut Flowers. Unpublished Thesis, Faculty of Agric., Alexandria University.

Mohammadi, G. A., A. S. Sardoei and M. Shahdadneghad. (2014). Improvement of the Vase Life of Cut Gladiolus Flowers by Salicylic Acid and Putrescine. Int J. Adv. Biol. Biom. Res., 2(2):417-426. 
Mohammadi, M., D. Hashemabadi and B. Kaviani. (2012). Improvement of Vase Life of Cut Tuberose (Polianthes tuberosa CV. 'Single') with Aluminum Sulfate. Annals of Biological Research, 3 (11):5181-5185.

Nader, M. S., Y. D. Shuraki and H. R. Mobasser. (2015). Influence of aluminum sulfate and copper sulfate on some characteristic in Rosa hybrid. Journal of Biodiversity and Environmental sciences, 6(1), 56-61.

Reid, M.S. (1989). The role of ethylene in flower senescence. Acta. Hort., 261: 157-169.

Roodbaraky, F., D. Hashemabad and S. HajiVand. (2012). Effect of Salicylic Acid on Vase Life of Cut Carnation (Dianthus caryophyllusL. cv. 'Liberty Abgr'). Annals of Biological Research, 3(11):5127-5129.

Sabzi, A., E. Hadavi and J. Hekmati. (2012). Effect of Different Levels of Malic acid and Salicylic Acid in Preservative Solution on the Quality and Vase Life of Cut Rose Flowers Cultivars (Utopia). International Journal of Agri. Science, 2(5): 403-407.

Sardoei, A.S. (2014). Effect of Gibberellic Acid and Calcium chloride on Keeping Quality and Vase Life of Narcissus (Narcissus Tazetta) Cut Flowers. International Journal of Plant, Animal and Environmental Sciences, 4(2): 2231-4490.

SAS inst. Inc. (2002). Statistical Analysis Software®. Cary, in.NC: SAS Institute Inc. USA.

Seyedi, N. A., A. Torkashvand, A. Mohammadi and M.S. Allahyari. (2013). Investigating of the Effects of Calcium Concentration under Hydroponic Conditions on Quantitative and Qualitative Growth of Lilium 'Tresor. Journal of Ornamental and Horticultural Plants, 3(1) 19-24.

Seyf, M., A. Khalighi, Y. Mostofi and R. Naderi. (2012). Study on the Effect of Aluminum Sulphate Treatment on Postharvest Life of the Cut Rose 'Boeing' (Rose hybrid cv. Boeing). Journal of Horticulture, forestry and Biotechnology, 16(3):128-132.

Soleimany- Fard, E., K. Hemmati and A. Khalighi. (2013). Improving the Keeping Quality and Vase Life of Cut Alstroemeria Flowers by Pre and Post-harvest Salicylic Acid Treatments. Nat. Sci. Biol., 5(3).

Steel, R. G. and J. M. Torrie. (1980). Principles and Procedures of Statistics. Mc Graw-Hill Co. Inc., New York.

Tehranifar, A., N. Vahdati, Y. Selahvarzi and H. Bayat. (2013). Treatment with Salicylic Acid Extends the Vase Life of Important Commercial Cut Flowers. Advanced Crop Science, 13(6):405-413.

Tsegaw, T., S. Tilahun and G. Humphries. (2011). Influence of pulsing biocides and preservative solution treatment on the vase life of cut rose (Rosa hybrida L.) varieties. Ethiop .J. Appl. Sci. Technol., 2(2):1-18.

USDA. (2012). Agricultural Statistics Service. Floricultural Crops Summary.

Viradia, R.R., A. Bajad and N.D. Polara. (2015). Value Addition through Use of Dye Chemicals and Floral Preservatives in Tuberose (Polianthes Tuberosa L.) Cv. Double. International Journal of Forestry and Horticulture, 1(1): 1-4.

Yadava, L. (1986). A Rapid and Non-destruction Method to Determine Chlorophyll in Intact Leaves. Hort Science, 21: 1449-1450.

Zadeh L. Y. and A. Mirzakhani. (2012). Study Effect of Thyme Oil, Salicylic Acid, Aloe Vera Gel and Some Chemical Substances on Increasing Vase 
Life of Cut (Dianthus caryophyllus cv. Liberty). Intl. J. Agron. Plant. Prod, 3(S): 666-674.

Zamani, S., M. Kazemi and M. Aran.(2011). Postharvest Life of Cut Rose Flowers as Affected by Salicylic Acid and Glutamine. World Applied Sciences Journal, 12 (9): 1621-1624.

$$
\text { الملخص العربى }
$$

تأثير بعض محاليل الحفظ على عمر أزهار الجلاديولس المقطوفة

\section{ثناء مصطفى عز' ، محمود أحمد على'، بثينة محمد وحيدة' محمد قرى جابر'

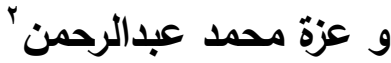

ا ـ قسم الانتاج النباتى - كلية زراعة سابا باشا- جامعة الاسكندرية.

• معهد بحوث البساتين

تعتبر المحافظة على جودة وعمر الأزهار من العوامل الهامة لتقييم جودة زهور القطف فى كل من الأسواق المحلية وأسواق التصدير • تهدف هذه الدراسة إلى تحديد فعالية بعض محاليل الحفظ منل حمض الجلوتاميك (. . . و ...

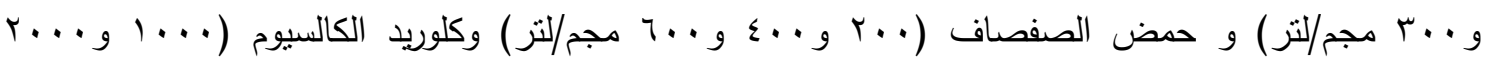

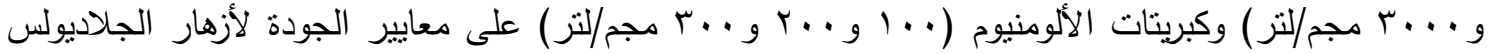
صنف "Rose Supreme". أظهرت النتائج أن كل المعاملات أدت إلى زيادة معنوية فى عمر الأزهار والوزن الطازج و كمية الماء المنص ومحتوى الكلوروفيل مع خفض عدد البكتبريا وتراكم البرولين مقارنة بالكنترول. تم

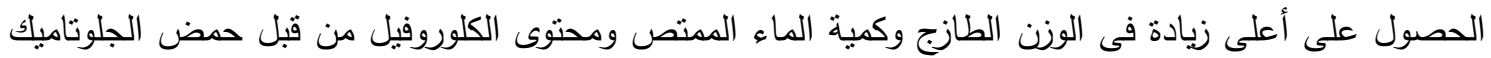

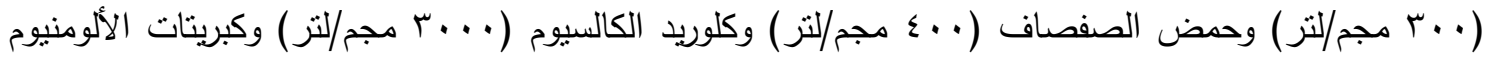

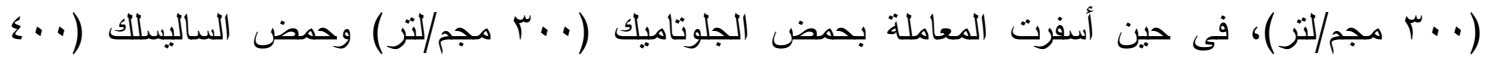
مجم/لتر) عن أطول مدة بقاء للأزهار فى كلا التجربتين، بلإضافة إلى حمض الجلوتاميك (.... مجم/لتر)

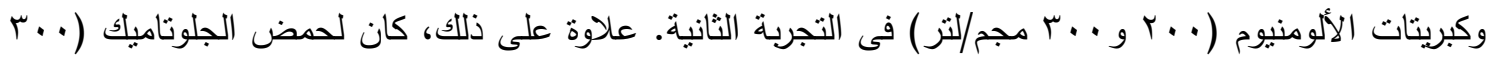

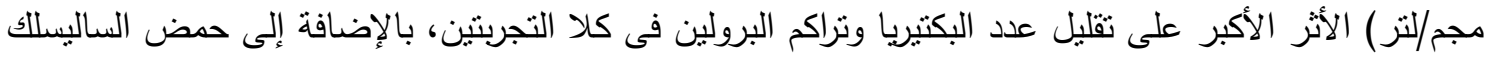

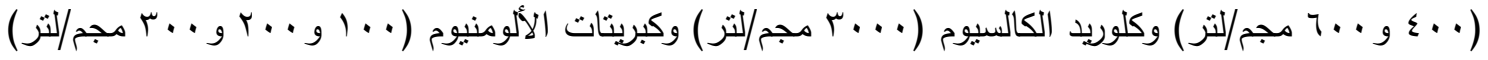

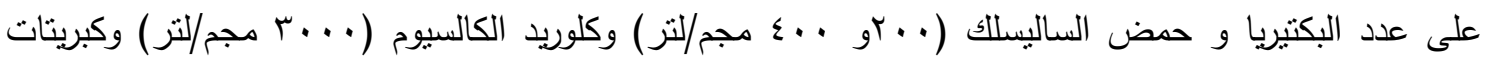

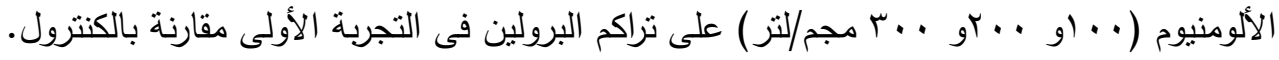

